ISSN 1678-3921

Journal homepage: www.embrapa.br/pab

For manuscript submission and journal contents, access: www.scielo.br/pab

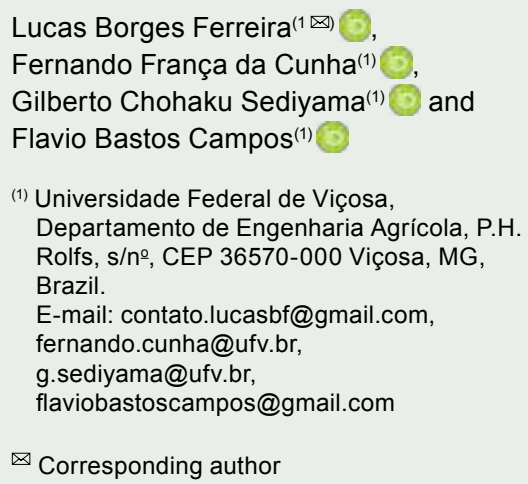

\section{HS Cal software for the calibration of the Hargreaves- Samani equation}

\begin{abstract}
The objective of this work was to develop a software (HS Cal) to calibrate the Hargreaves-Samani equation for specific periods of the year, in global, seasonal, and monthly time scales, as well as to compare the performance of calibrated and non-calibrated equations. The software was developed in order to use raw data provided by Banco de Dados Meteorológicos para Ensino e Pesquisa (BDMEP). All calibrations outperformed the original Hargreaves-Samani equation, especially with the use of seasonal and monthly calibrations. The HS Cal software can easily calibrate the Hargreaves-Samani equation, allowing the identification of the best form of this equation for a given site.
\end{abstract}

Index terms: agrometeorology, irrigation, local calibration, minimum data, reference evapotranspiration, simplified models.

\section{Programa HS Cal para calibração da equação de Hargreaves-Samani}

Resumo - O objetivo deste trabalho foi desenvolver um programa (HS Cal) para calibrar a equação de Hargreaves-Samani para períodos específicos do ano, nas escalas global, sazonal e mensal, bem como comparar o desempenho das equações calibrada e não calibrada. O software foi desenvolvido para o uso de dados brutos fornecidos pelo Banco de Dados Meteorológicos para Ensino e Pesquisa (BDMEP). Todas as calibrações estudadas superaram a equação de Hargreaves-Samani original, especialmente com uso das calibrações sazonal e mensal. O programa HS Cal pode calibrar facilmente a equação de Hargreaves-Samani, o que possibilita a identificação da melhor forma desta equação para uma dada localidade.

Termos para indexação: agrometeorologia, irrigação, calibração local, dados mínimos, evapotranspiração de referência, modelos simplificados.

The reference evapotranspiration $\left(\mathrm{ET}_{\mathrm{o}}\right)$ can be well estimated by the Penman-Monteith (PM) equation, recommended by the Food and Agriculture Organization as the standard method (Allen et al., 1998). However, this equation requires a large number of meteorological parameters (air temperature, relative humidity, wind speed, and solar radiation), which reduces its applicability (Ballesteros et al., 2016).

As an alternative to the PM equation, it is possible to use the wellknown Hargreaves-Samani (HS) equation, when only temperature data are available. However, because it is a simplified equation, its performance varies according to the climatic conditions of where it is used (Maestre-Valero et al., 2013), indicating that local calibration is 
required to obtain better $\mathrm{ET}_{\mathrm{o}}$ estimates (Liu et al., 2017). The HS equation also presents different performances throughout the year due to climatic variations (Martí et al., 2015), suggesting that better ET $_{\mathrm{o}}$ estimates could be achieved by also performing calibrations for certain periods of the year.

One of the main sources of historical meteorological data for the calibration of the HS equation available in Brazil is the database Banco de Dados Meteorológicos para Ensino e Pesquisa (BDMEP). However, for data use, several hours are usually required to adjust data structure and to eliminate inconsistent values.

The objective of this work was to develop a software (HS Cal) to calibrate the HS equation for specific periods of the year, as well as to compare the performance of calibrated and non-calibrated equations in global, seasonal, and monthly time scales.

A software called HS Cal was developed to calibrate the HS equation by means of simple linear regression, using the PM equation as a benchmark. The Java programming language was used. This software aims to make possible the calibration of the HS equation using daily meteorological data from BDMEP in Brazil, without the need of preprocessing by the user, due to the algorithm created to identify data structure and eliminate days with missing or inconsistent data. Data considered as inconsistent were those that presented minimum temperature greater than maximum temperature; negative sunshine duration or sunshine duration greater than the photoperiod; negative or greater than $100 \%$ relative humidity; and wind speed with negative value or greater than $15 \mathrm{~m} \mathrm{~s}^{-1}$ at $10 \mathrm{~m}$ height.

The software read the data (maximum and minimum air temperatures, relative humidity, wind speed, and sunshine duration) from a text file (Figure 1) containing the structured information provided by BDMEP without any prior transformation. This file must contain the same header used by BDMEP, with information about the accessed weather station, so that the software is able to identify the location of the station, which is necessary for $\mathrm{ET}_{\mathrm{o}}$ calculation. The software converts the wind speed at $10 \mathrm{~m}$ height (standard height used in BDMEP) to $2 \mathrm{~m}$ and estimates the solar radiation based on sunshine duration, according to Allen et al. (1998).

Daily $\mathrm{ET}_{\mathrm{o}}$ was calculated with the PM and HS equations, and then calibration parameters were determined by simple linear regression, as described by Allen et al. (1998). For this, a linear equation was established, in which the $\mathrm{ET}_{\mathrm{o}}$ estimated by HS is considered as an independent variable and the one estimated by PM as a dependent variable. The obtained intercept (a) and slope (b) are used as calibration parameters. Therefore, the calibrated $\mathrm{ET}_{\mathrm{o}}$ is obtained by multiplying the $\mathrm{ET}_{\mathrm{o}}$ of the HS equation by calibration parameter $b$ plus calibration parameter a, as in: $\mathrm{ET}_{0}=\mathrm{a}+\mathrm{b}\left(\mathrm{ET}_{\mathrm{OHS}}\right)$.

The $\mathrm{a}$ and $\mathrm{b}$ parameters were obtained considering the data as a whole (global scale), or considering specific seasons (seasonal scale) or months (monthly scale). For the seasonal scale, summer comprehended months 1,2 , and 3; fall, months 4,5 , and 6 ; winter, months 7, 8, and 9; and spring, months 10, 11, and 12 .

For the calibration performance test, two options are available: use of independent or of common data. In the first option, data are randomized and, later, $70 \%$ of them are used in the calibration process, while the other $30 \%$ are used for the testing process. In the second option, all data is used both in the calibration and test processes. It should be emphasized that the developed algorithm considers negative $\mathrm{ET}_{\mathrm{o}}$ values as zero, after calibration.

For the performance test, the following statistical indices were used: root mean square error (RMSE), mean absolute error (MAE), mean bias error (MBE), Willmott's index of agreement (d), correlation coefficient ( $\mathrm{r}$ ), coefficient of determination $\left(\mathrm{R}^{2}\right)$, and performance index $(\mathrm{C})$. The following equations were used:

$\operatorname{RMSE}=\left[1 / \mathrm{n} \times \Sigma\left(\mathrm{P}_{\mathrm{i}}-\mathrm{O}_{\mathrm{i}}\right)\right]^{0.5}, \mathrm{MAE}=1 / \mathrm{n} \times \Sigma\left|\mathrm{P}_{\mathrm{i}}-\mathrm{O}_{\mathrm{i}}\right|$, $\mathrm{MBE}=1 / \mathrm{n} \times \Sigma\left(\mathrm{P}_{\mathrm{i}}-\mathrm{O}_{\mathrm{i}}\right), \mathrm{d}=1-\Sigma\left(\mathrm{P}_{\mathrm{i}}-\mathrm{O}_{\mathrm{i}}\right)^{2} / \Sigma\left(\left|\mathrm{P}_{\mathrm{i}}-\overline{\mathrm{O}}\right|+\right.$ $\left.\left|\mathrm{O}_{\mathrm{i}}-\overline{\mathrm{O}}\right|\right)^{2}, \mathrm{r}=\Sigma\left(\mathrm{P}_{\mathrm{i}}-\overline{\mathrm{P}}\right)\left(\mathrm{O}_{\mathrm{i}}-\overline{\mathrm{O}}\right) /\left[\Sigma\left(\mathrm{P}_{\mathrm{i}}-\overline{\mathrm{P}}\right)^{2} \Sigma\left(\mathrm{O}_{\mathrm{i}}-\overline{\mathrm{O}}\right)^{2}\right]^{0.5}$, $\mathrm{R}^{2}=\mathrm{r}^{2}$, and $\mathrm{C}=\mathrm{d} \times \mathrm{r}$, where $\mathrm{P}_{\mathrm{i}}$ is the value predicted by the model (mm per day), $\mathrm{O}_{\mathrm{i}}$ is the observed value ( $\mathrm{mm}$ per day), $\overline{\mathrm{P}}$ is the mean of the values predicted by the model, $\overline{\mathrm{O}}$ is the mean of the observed values, and $\mathrm{n}$ is the number of data pairs. It should be noted that the $\mathrm{C}$ value was classified according to the criteria proposed by Camargo \& Sentelhas (1997), which is: $>0.85$, great; $0.76-0.85$, very good; $0.66-0.75$, good; 0.61-0.65, medium; 0.51-0.60, not good; 0.41-0.50, bad; and $<0.40$, terrible.

The software provides the results in commaseparated values (CSV) file format, compatible with Microsoft Excel. The output file content includes calibrations parameters, statistical indices for measuring 
the performance of calibrated and non-calibrated equations, and the $\mathrm{ET}_{0}$ values used in the calibration and test processes. Since the language used in the software is Portuguese, the decimal separator is the comma. To open the file, the spreadsheet software must be configured with the comma as a decimal separator.

A case study was carried out to test the HS Cal software, using data from ten Brazilian locations (municipalities): Barreiras, in the state of Bahia; Belém, in the state of Pará; Campina Grande, in the state of Paraíba; Canarana, in the state of Mato Grosso; Curitiba, in the state of Paraná; Januária, in the state of Minas Gerais; Manaus, in the state of Amazonas; Rio Branco, in the state of Acre; Santa Maria, in the state of Rio Grande do Sul; and Sorocaba, in the state of São Paulo (Table 1). The locations were selected aiming to cover various climatic conditions, by choosing points in several states of Brazil. The data used refers to the period from 2006 to 2015 . The performance test was carried out with independent data, according to the recommendations of Shiri et al. (2015).
The performances of the calibrated and noncalibrated HS equations were classified according to the criteria proposed by Camargo \& Sentelhas (1997).

The HS Cal software is available for Windows and Mac OS, in the Portuguese language, and can be accessed for free at the website of Grupo de Estudos e Soluções para Agricultura Irrigada (Gesai, 2019). It was able to provide the calibration parameters for the HS equation in both a simple and fast manner. The software can also be useful for estimating $\mathrm{ET}_{0}$ for long time periods, which can help to better the designs of irrigation projects in regions where a BDMEP weather station is available.

The performances of the original and calibrated HS equations are shown in Table 1. The calibrated equations outperformed the original HS equation, especially for seasonal and monthly calibrations. The software can easily calibrate the HS equation, allowing the identification of the best form of this equation for a given site.

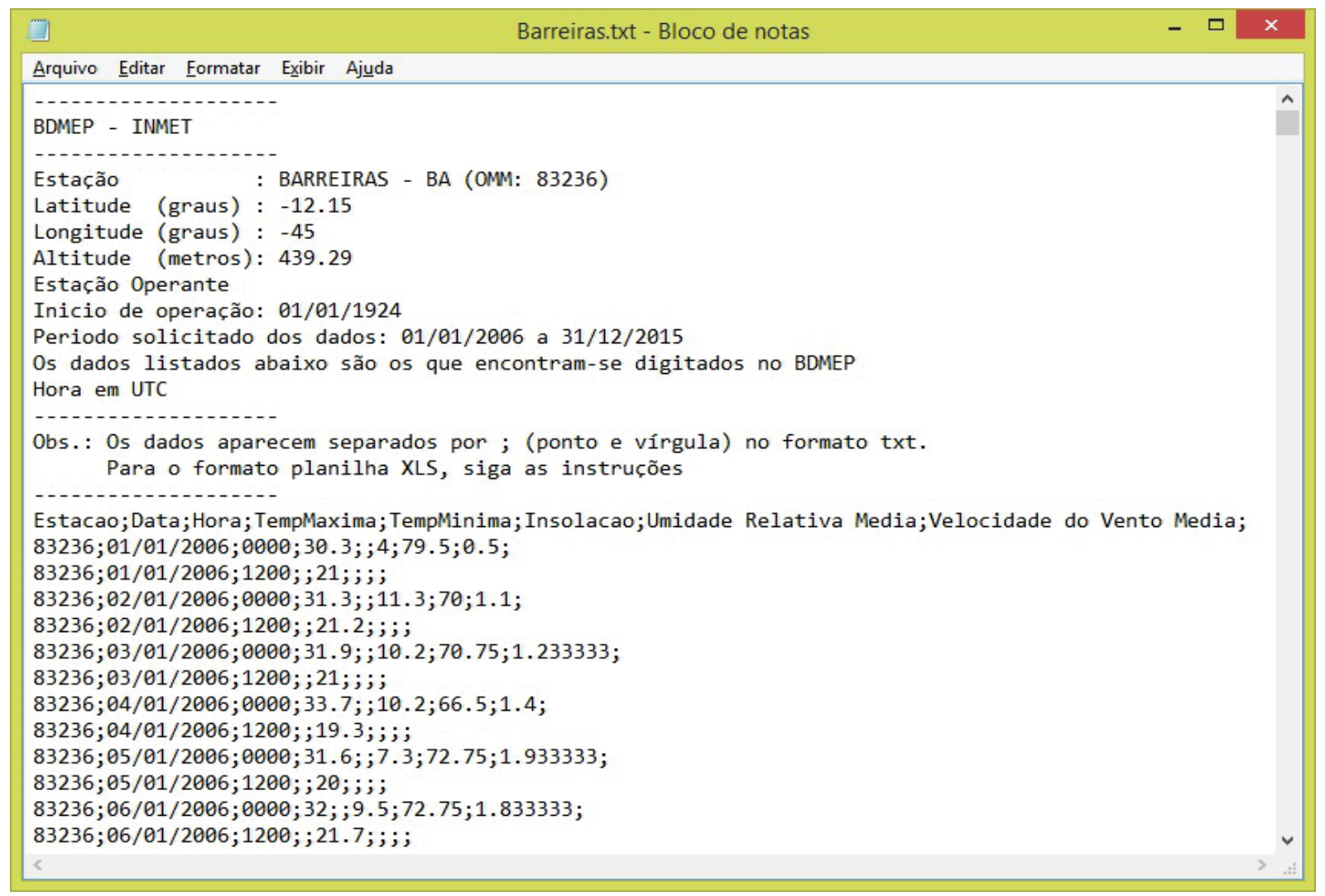

Figure 1. Example of input file for the HS Cal software. BDMEP, Banco de Dados Meteorológicos para Ensino e Pesquisa, Brazilian database of meteorological data; and INMET, Instituto Nacional de Meteorologia, meteorological service of Brazil. 
Table 1. Performance test and calibrations of the Hargreaves-Samani equation (HS) according to global (HS global), seasonal (HS season), and monthly (HS month) time scales at ten locations (municipalities) in Brazil.

\begin{tabular}{|c|c|c|c|c|}
\hline Statistical index ${ }^{(1)}$ & HS & HS global & HS season & HS month \\
\hline & \multicolumn{4}{|c|}{ Barreiras, BA } \\
\hline RMSE (mm per day) & 1.09 & 0.73 & 0.71 & 0.70 \\
\hline \multirow[t]{2}{*}{ Classification } & Medium & Good & Good & Good \\
\hline & \multicolumn{4}{|c|}{ Belém, PA } \\
\hline RMSE (mm per day) & 0.87 & 0.58 & 0.51 & 0.50 \\
\hline \multirow[t]{2}{*}{ Classification } & Not good & Medium & Good & Good \\
\hline & \multicolumn{4}{|c|}{ Campina Grande, PB } \\
\hline RMSE (mm per day) & 0.59 & 0.54 & 0.53 & 0.52 \\
\hline \multirow[t]{2}{*}{ Classification } & Very good & Very good & Great & Great \\
\hline & \multicolumn{4}{|c|}{ Canarana, MT } \\
\hline RMSE (mm per day) & 1.61 & 0.63 & 0.59 & 0.58 \\
\hline \multirow[t]{2}{*}{ Classification } & Terrible & Not good & Medium & Medium \\
\hline & \multicolumn{4}{|c|}{ Curitiba, $\mathrm{PR}$} \\
\hline RMSE (mm per day) & 0.91 & 0.55 & 0.54 & 0.53 \\
\hline \multirow[t]{2}{*}{ Classification } & Very good & Great & Great & Great \\
\hline & \multicolumn{4}{|c|}{ Januária, MG } \\
\hline RMSE (mm per day) & 0.89 & 0.74 & 0.66 & 0.64 \\
\hline \multirow[t]{2}{*}{ Classification } & Good & Good & Very good & Very good \\
\hline & \multicolumn{4}{|c|}{ Manaus, AM } \\
\hline RMSE (mm per day) & 0.97 & 0.71 & 0.67 & 0.65 \\
\hline \multirow[t]{2}{*}{ Classification } & Not good & Medium & Good & Good \\
\hline & \multicolumn{4}{|c|}{ Rio Branco, AC } \\
\hline RMSE (mm per day) & 1.25 & 0.56 & 0.53 & 0.52 \\
\hline \multirow[t]{2}{*}{ Classification } & Not good & Good & Good & Good \\
\hline & \multicolumn{4}{|c|}{ Santa Maria, RS } \\
\hline RMSE (mm per day) & 0.97 & 0.67 & 0.68 & 0.69 \\
\hline \multirow[t]{2}{*}{ Classification } & Very good & Great & Great & Great \\
\hline & \multicolumn{4}{|c|}{ Sorocaba, SP } \\
\hline RMSE (mm per day) & 1.09 & 0.52 & 0.52 & 0.50 \\
\hline Classification & Very good & Great & Great & Great \\
\hline
\end{tabular}

(1)RMSE, root mean square error; and Classification, according to Camargo \& Sentelhas (1997). Brazilian states: BA, Bahia; PA, Pará; PB, Paraíba; MT, Mato Grosso; PR, Paraná; MG, Minas Gerais; AM, Amazonas; AC, Acre; RS, Rio Grande do Sul; and SP, São Paulo.

\section{Acknowledgments}

To Conselho Nacional de Desenvolvimento Científico e Tecnológico (CNPq), for scholarship to the first author.

\section{References}

ALLEN, R.G.; PEREIRA, L.S.; RAES, D.; SMITH, M. Crop evapotranspiration: guidelines for computing crop water requirements. Rome: FAO, 1998. 297p. (FAO Irrigation and Drainage Paper, 56).

BALLESTEROS, R.; ORTEGA, J.F.; MORENO, M.Á. FORETo: new software for reference evapotranspiration forecasting. Journal of Arid Environments, v.124, p.128-141, 2016. DOI: https://doi.org/10.1016/j.jaridenv.2015.08.006.
CAMARGO, Â.P. de; SENTELHAS, P.C. Avaliação do desempenho de diferentes métodos de estimativa da evapotranspiração potencial no Estado de São Paulo, Brasil. Revista Brasileira de Agrometeorologia, v.5, p.89-97, 1997.

GESAI. Grupo de Estudos e Soluções para Agricultura Irrigada. Software HS CAL. Available at: <http://www.gesai.ufv. br/?page_id=344>. Accessed on: June 212019.

LIU, X.; XU, C.; ZHONG, X.; LI, Y.; YUAN, X.; CAO, J. Comparison of 16 models for reference crop evapotranspiration against weighing lysimeter measurement. Agricultural Water Management, v.184, p.145-155, 2017. DOI: https:/doi. org/10.1016/j.agwat.2017.01.017.

MAESTRE-VALERO, J.F.; MARTÍNEZ-ÁLVAREZ, V.; GONZÁLEZ-REAL, M.M. Regionalization of the Hargreaves coefficient to estimate long-term reference evapotranspiration series 
in SE Spain. Spanish Journal of Agricultural Research, v.11, p.1137-1152, 2013. DOI: https://doi.org/10.5424/sjar/2013114-3869.

MARTÍ, P.; ZARZO, M.; VANDERLINDEN, K.; GIRONA, J. Parametric expressions for the adjusted Hargreaves coefficient in Eastern Spain. Journal of Hydrology, v.529, p.1713-1724, 2015. DOI: https://doi.org/10.1016/j.jhydrol.2015.07.054.
SHIRI, J.; SADRADDINI, A.A.; NAZEMI, A.H.; MARTI, P.; FARD, A.F.; KISI, O.; LANDERAS, G. Independent testing for assessing the calibration of the Hargreaves-Samani equation: new heuristic alternatives for Iran. Computers and Electronics in Agriculture, v.117, p.70-80, 2015. DOI: https://doi.org/10.1016/j. compag.2015.07.010. 